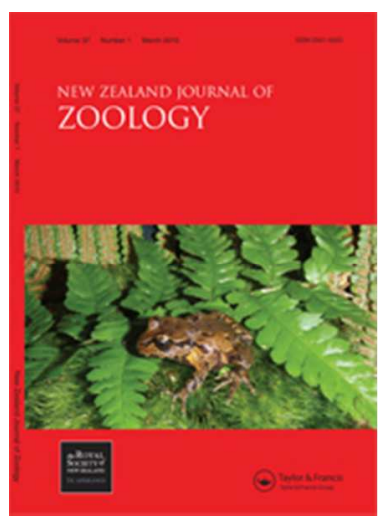

\title{
Variation in mandible shape and body size of house mice Mus musculus in five separate New Zealand forest habitats
}

\begin{tabular}{|r|l|}
\hline Journal: & New Zealand Journal of Zoology \\
\hline Manuscript ID & NZJZ-2017-0021.R2 \\
\hline Manuscript Type: & Research Paper \\
\hline Date Submitted by the Author: & $28-N o v-2017$ \\
\hline Complete List of Authors: & $\begin{array}{l}\text { West, Annie; University of Auckland, School of Biological Sciences } \\
\text { King, Carolyn; RSNZ/University of Waikato, Biological Sciences }\end{array}$ \\
\hline Keywords: & $\begin{array}{l}\text { geometric morphometrics, island, New Zealand, castaneus, domesticus, } \\
\text { environmental variables, mandible shape, body size, house mouse, insular }\end{array}$ \\
\hline
\end{tabular}




\title{
Variation in mandible shape and body size of house mice Mus musculus in five separate New Zealand forest habitats
}

\author{
Authors: Annie G. West ${ }^{1}$ \& Carolyn M. King ${ }^{2}$ \\ ${ }^{1}$ Current address: awes313@aucklanduni.ac.nz, School of Biological Sciences, University of Auckland, NZ \\ ²mking@waikato.ac.nz, School of Science, University of Waikato, NZ
}

\section{ABSTRACT}

This study investigates variation in house mouse Mus musculus body size and mandible shape across New Zealand, using geometric morphometrics and biomechanical advantage analyses. The Mus phylogroups currently known in New Zealand include Mus musculus domesticus, M. m. musculus, and M. m. castaneus. We examined samples of house mice inhabiting five different podocarp and beech forest environments across the North and South Islands (Pureora Forest, Zealandia Wildlife Sanctuary, Craigieburn Forest Park, Eglinton Valley, and Hollyford Valley). Significant variation in mandible shape and body size was found between all five forest populations. South Island mice had larger bodies and greater mechanical advantage in the temporalis muscles compared with their North Island counterparts. Zealandia Sanctuary mouse mandibles were broader and shorter than South Island mouse mandibles, and had greater masseter muscle advantage. Centroid size and body weight, but not head-body length, varied significantly with two distinct genetic haplotypes . Finally, annual rainfall was the most significant covariate with mandible shape. Higher rainfall locations were generally associated with soft-food related mandible shapes, while lower rainfall correlated with hard-food mandible shapes. This preliminary investigation provides the framework for further research into mandible shape and body size variation in New Zealand house mice.

\section{INTRODUCTION}

The house mouse Mus musculus (L. 1758) is a prevalent pest species in New Zealand, introduced by European seafarers in the early $19^{\text {th }}$ century. Genetic elements of three subspecies of house mice have reached the New Zealand archipelago: Musculus musculus domesticus, M. m. castaneus, and M. m. musculus (Searle et al. 2009 King et al. 2016). On the New Zealand 'mainland' (North and South Islands) M. m. castaneus and M. m. 
musculus elements are observed in hybrid mice primarily as mitochondrial DNA, as the nuclear genome is characterized almost entirely by M. m. domesticus DNA (Searle et al. 2009; A. Veale et al unpubl.).

Mice are widespread across the North and South Islands, populating a variety of habitats from vegetated coastal sand dunes to forests to alpine grasslands (Ruscoe et al. 2004; Ruscoe \& Murphy 2005; O’Donnell et al. 2017). Dense ground cover tends to be their preferred habitat, offering access to both food and safety (King et al. 1996a; Ruscoe \& Murphy 2005; O’Donnell et al. 2017). Seed masting, a cycle of periodic heavy seedfalls (Norton \& Kelly 1988), provides abundant food in some years, which facilitate extended winter breeding (King 1983; Murphy 1992; Choquenot \& Ruscoe 2000; O’Donnell et al. 2017). House mouse populations are known to irrupt in tussock grassland (Chionochloa), and in beech forest and hardwood-podocarp forest following seed masting events (King 1983; Fitzgerald et al. 1996; O’Donnell et al. 2017). Abundant flowers and seeds ultimately drop from the trees and enrich the forest litter. This enrichment enables greater recruitment of invertebrates, especially caterpillars, resulting in a chain of resource pulses in beech forest habitats (King 1983; Fitzgerald et al. 1996; Wilson \& Lee 2010).

House mice in New Zealand are flexible omnivores, consuming a variety of seeds and invertebrates, but are also known to eat lizards and small avian chicks and eggs (Ruscoe \& Murphy 2005; Russell 2012; O’Donnell et al. 2017). In some studies on sub-Antarctic islands, the diet of house mice was repeatedly dominated by invertebrates, a marked dietary shift from their continental counterparts (Copson 1986; Le Roux et al. 2002; Renaud et al. 2015).

New Zealand-based studies have found that house mice free of competition and predation from ship rats (Rattus rattus), cats and stoats show a significant increase in detection rates after poisoning operations that may indicate an ecological release of mouse populations (Innes et al. 1995; Goldwater et al. 2012). Goldwater et al. (2012) observed that mice free from mammalian predators and competitors were significantly heavier than usual. Bridgman et al. (2013) showed that house mice also restricted their activities in the presence of ship rats. 
Furthermore, island invasion by small continental mammals is often followed by an increase in body size, a trend known as the island rule or syndrome (Adler \& Levins 1994; Lomolino et al. 2005). This change in body mass is typically attributed to variation in resource abundance, which can be influenced by a number of environmental factors including climate and island size (Medina et al. 2007; Millien 2011; Lomolino et al. 2012).

Mandible shape and function are influenced by diet, particularly in response to variation in the regular consumption of hard and soft food groups (Michaux et al. 2007; Anderson et al. 2014). Here we ask whether and in what ways did the ancestors of mice colonising New Zealand successfully adjust to novel food items, and whether those adjustments also prompted changes in the jaw morphology to facilitate altered mandible function (Michaux et al. 2007; Renaud et al. 2015; Ledevin et al. 2016).

The mandible is a very malleable bone that is responsive to changes in the strength and activity of the muscles pulling on the jaw (Satoh 1997; Michaux et al. 2007; Baverstock et al. 2013). Distinct components of the mandible include: the ramus (comprised of the coronoid process, angular process, and condyle process), and the alveolar region (Figure 1; Michaux et al. 2007) (Hiiemae 1971a; Satoh 1997; Michaux et al. 2007). The ability of the mandible to produce gnawing and chewing actions depends on the strength of the muscles that facilitate these movements, and the support of the associated bone regions to which they attach (Hiiemae 1971a; Klingenberg \& Navarro 2012; Baverstock et al. 2013). The condyle process controls the interaction of the mandible bone joint with the cranium, whereas the coronoid and angular processes are the respective attachment sites for temporalis and masseter muscle groups (Hiiemae 1971a; Klingenberg \& Navarro 2012; Baverstock et al. 2013). The masseter muscle facilitates molar mastication activity, enabling the mouse to grind up tough plant material, whereas the temporalis muscle enables occlusion of the incisor teeth for gnawing and prey catching activities (Hiiemae 1971a, b; Crompton \& Parker 1978; Satoh 1997; Baverstock et al. 2013). Michaux et al. (2007) note that mandible shape is strongly related to the insertion and activity of the masticatory muscles (Satoh 1997).

[Here Figure 1] 
Mandible shape is also very sensitive to changes in the relative hardness of food items (Renaud \& Auffray 2010; Anderson et al. 2014; Renaud et al. 2015). Resistant foods will require a larger mechanical force for processing and breakdown compared with softer food items (Michaux et al. 2007; Anderson et al. 2014; Renaud et al. 2015). A shorter, broader mandible can apply greater mechanical force than a slimmer, elongated one by increasing the strength of force exerted by the masseter muscle (Satoh 1997; Michaux et al. 2007). Living bone is constantly remodelled throughout life, allowing the mandible to be flexible enough to compensate for changes in diet that require altered bite force. This capability makes the mandible one of the most useful materials for detecting adaptive changes (Michaux et al. 2007; Siahsarvie et al. 2012; Renaud et al. 2015). It is therefore reasonable to expect mice inhabiting different habitats around New Zealand to vary in body and mandible morphology. Genetic hybridisation can also have a significant influence on mandible size and shape (Scriven \& Bauchau 1992; Renaud et al. 2010; Renaud et al. 2012).

Geometric morphometrics is a technique permitting accurate descriptions of changes in biological shape (Bookstein 1991; Rohlf 2005; Klingenberg 2016). It provides mathematical descriptions of shape variables excluding influencing variables such as size, rotation, and position, as well as controlling for allometry (Dryden \& Mardia 1998; Zelditch et al. 2012). The mathematic basis of this technique offers precise shape descriptions in the form of landmark coordinates that can be rigorously tested with common-place multivariate statistical analyses (Slice 2007; Cooke \& Terhune 2015). Geometric morphometrics is employed in this study to explore variation between house mouse populations in mandible shape at a more subtle level than is possible by traditional methods.

Past studies on mouse populations show that 100 years is enough time for mandible shape changes to develop, especially on islands (Berry 1964; Millien 2011; Doudna \& Danielson 2015; Renaud et al. 2015).

This study compares the size and shape of mandibles and the body measurements of house mice from five New Zealand forest habitats differing in climate, plant community, and presence or absence of other invasive 
mammals. The variation in plant species between habitat types is likely to influence the major dietary components of house mouse populations.

\section{MATERIALS}

The study areas of interest are Pureora Forest and Zealandia Wildlife Sanctuary of the North Island, and Craigieburn Forest Park, Eglinton Valley, and Hollyford Valley of the South Island (Table 1). A total of 105 individuals from North and South Island forests were studied (Table 2). The University of Waikato provided precleaned skulls from Hollyford Valley, Eglinton Valley, and Craigieburn Forest Park, collected during 1974-76, 1973-80, and 1975-80 respectively by King (1983), and from Pureora Forest during 1982-87 by King et al. (1996a, b). Frozen whole body samples were collected from Zealandia Wildlife Park in Karori, Wellington, from mice that had been captured or poisoned over the last few years.

Pureora Forest supports a mixture of mature native podocarp, including tawa (Beilschmiedia tawa), rimu (Dacrydium cupressinum), matai (Prumnopitys taxifolia), miro (Prumnopitys ferruginea), tōtara (Podocarpus totara), kamahi (Weinmannia racemose), wheki (Dicksonia squarrosa) and tree fern (Cyathea smithii), and exotic Pinus radiata forest (King et al. 2015). A previous study by King et al. (1996a) found mice were most abundant in a young plantation area, where ground cover was most dense. The Zealandia Wildlife Sanctuary spans a 252 ha section of regenerating broadleaf forest enclosed by a predator-proof fence (Blick et al. 2008). The vegetation is dominated by coastal broadleaf-conifers such as mähoe (Melicytus ramiflorus), five finger (Pseudopanax arboreus), and pate (Schefflera digitata), interspersed with exotic Pinus radiata stands (Blick et al. 2008). As the Zealandia forest is in succession, tree ferns (Cyathea spp.), vines and shrubs e.g. hangehange (Geniostoma rupestre) and kawakawa (Macropiper excelsum), contribute to a dense understory beneath a closed canopy, with few emergent trees. Craigieburn Forest Park is predominantly mountain beech (Fuscospora cliffortioides), giving way to alpine grasslands above the treeline (King 1983). Red beech (Fuscospora fusca), one of only eight plant species offering food for mice, dominates the Eglinton Valley Forest (King 1983). By contrast, the trap line in the Hollyford Valley ran along a diverse transect, supporting 28 species of foodbearing plants including silver beech (Lophozonia menziesii). 
Mandible shape is not known to be significantly associated with sexual dimorphism in wild mice, so gender was not distinguished in this study (Davis 1983; Renaud 2005; Siahsarvie et al. 2012). Only adult specimens with the third molar erupted were included, as per previous geometric morphometric studies on house mice (Renaud \& Auffray 2010; Siahsarvie et al. 2012; Renaud et al. 2015). House mice inhabiting Craigieburn and Pureora Forest Parks were assumed to represent haplotype M. m. domesticusNZ.4 (King et al. 2016). Eglinton and Hollyford valley mice represent the domesticus - castaneusNZ.1 hybrid strain (King et al. 2016). Zealandia mice could not be individually haplotyped for this study, and so were assumed to represent mostly domesticus castaneusNZ.1 hybrids, but may also have included domesticus and musculus elements (see King et al. 2016). Body weight and length measurements were available for all samples (Table 2).

[Here Table 1]

\section{METHODS}

Mouse mandibles were cleaned either by dermestid beetles or by sodium perborate, a chemical method described by McDonald and Vaughan (1999). Photographs of each mouse mandible, with a scale ruler, were taken using a Leica MZ12 stereomicroscope with a Carl Zeiss Axiocam HRc camera. Sixteen two-dimensional homologous landmarks were digitized on the lateral mandible (Figure 2) using software TPSDig.2 ver.2.19. (Rohlf 2015).

[Here Figure 2]

\section{BODY SIZE COMPARISONS}

Body weight, tail length, head-body length and centroid size measurements were tested for normality using the Shapiro-Wilks test, and for unequal variances using the Brown-Forsythe test. Data were then compared between locations with univariate analysis of variance (ANOVA), with Dunnett's T3 correction, or nonparametric Kruskal-Wallis, with Bonferroni correction for multiple comparisons. Centroid size was regressed against body weight and head-body length, for which the adjusted $R^{2}$, total degrees of freedom (tdf) and 
significant $\mathrm{F}$ change ( $\mathrm{P}$-value) values are reported. Body weight, head-body length and centroid size were also regressed against genetic haplotype. These statistical analyses were carried out using SPSS v.24.

\section{BIOMECHANICAL ADVANTAGE}

Biomechanical advantage is a measure of bite force efficiency, derived by calculating the ratio of inlever to outlever forces. The inlevers correspond to the distance from the condyle to the attachment zones for the temporalis and masseter muscles (Figure 2). The outlevers measure the distance between the condyle and the tip of the incisor, and the main molar cusp. These measurements were replicated from Renaud et al. (2015) who conducted a biomechanical analysis on house mouse mandibles from Guillou Island, sub-Antarctic Kerguelen Archipelago. Four ratios for estimating biomechanical advantage were calculated: masseter/incisor $(\mathrm{M} / \mathrm{I})$, masseter/molar $(\mathrm{M} / \mathrm{M})$, temporalis/incisor $(\mathrm{T} / \mathrm{I})$ and temporalis/molar $(\mathrm{T} / \mathrm{M})$. The ratios were tested for normality and unequal variances using the Shapiro-Wilks and Brown-Forsythe tests, and subsequently compared between mouse populations with ANOVA followed by pairwise comparisons, with Dunnett's T3 correction, in SPSS.

\section{GEOMETRIC MORPHOMETRICS}

A Generalized Procrustes Fit (GPF) was performed on the coordinates obtained from TPSDig.2 in MorphoJ ver.1.06d (Klingenberg 2011) to quantify shape differences between individual configurations (Rohlf 1990; Dryden \& Mardia 1998; Rohlf 1999). GPF produces a local approximation of the arrangements in Kendall's tangent space in 2-dimensional format for the given data set (Kendall 1984, 1989; Zelditch et al. 2012; Klingenberg 2016). The Procrustes superimposition then removes mandible size (expressed as centroid size, derived from the square root of the sum of squared distances of all the landmarks from their centroid), position and orientation variables, resulting in Procrustes distances between corresponding landmarks that represent discrepancies between configurations i.e. a measure of shape differences (Dryden \& Mardia 1992; Kendall 1989; Zelditch et al. 2012; Klingenberg 2016). These shape differences are visualised by warped outline diagrams displaying the maximum Procrustes distance change for each landmark (Slice 2007). 


\section{CONTROLLING FOR ALLOMETRY}

To test for significant allometry (changes in shape caused by variation in body size) in the data set, a pooledgroup multivariate regression of shape (Procrustes coordinates) on log centroid size was performed (Monteiro 1999; Mitteroecker \& Gunz 2009; Klingenberg 2016). It is important to check if body size has any significant influence on shape, because we want to investigate the variation in mandible shape without allometry influencing the data. MANCOVA is included in the multivariate regression to test the homogeneity of the allometric slopes (Klingenberg 2016).

\section{PLOTTING THE SHAPE CHANGES}

A principal component analysis (PCA) was then conducted on the covariance matrix of the regression residuals to visualise variation between individual mandible shapes without allometry (Zelditch et al. 2012). Overall mandible shape change along the first two principal component axes were visualised using warped outline diagrams (Slice 2007). The number of PCs each accounting for $>5 \%$ of total variation is reported, as per similar geometric morphometric studies. A canonical variate analysis (CVA; Zelditch et al. 2012) was used to investigate differences between pre-defined groups. CVA produces Mahalanobis distances between groups, which are equivalent to the multi-dimensional measures of standard deviation between individual shapes and group means. The Mahalanobis distances can therefore indicate which pre-defined groups have the most similar and dissimilar mean mandible shapes. A warped outline diagram was used to visualise shape change along the CV axis. Both PCA and CVA were bootstrapped with 1000 repetitions. PCA and CVA provides permutation P-values for the computation of Procrustes and Mahalanobis distances. These statistical analyses were carried out using MorphoJ.

A two-block partial least squares analysis (PLS) was used to investigate the pattern of covariation of shape variables with genetic haplotype and environmental variables listed in Table 1 (Monteiro 1999; Zelditch et al. 2012). PLS also reduces the original shape coordinates onto a set of new axes that explain covariation between sets of variables, or blocks, in successional order (Zelditch et al. 2012). Again, shape change is visualised using 
warped outline diagrams. The RV coefficient is a common measure of association in PLS studies, and here is reported on a $0-1.0$ scale where 0 represents completely uncorrelated data. The permutation P-value for the RV coefficient, which tests the null hypothesis of complete independence for each PLS block, is reported. The PLS axis pairs accounting for $>5 \%$ of total variation are reported with covariation percentage and associated permutation P-value.

\section{RESULTS}

\section{BODY SIZE AND CENTROID SIZE COMPARISONS}

Eglinton Valley mice were the heaviest and had the longest tails, while Zealandia mice had the shortest tail and head-body length (Table 2; Figure 3). Pureora mice were the lightest, and Craigieburn mice had the longest head-body length (Table 2; Figure 3).

Body weight differed significantly in all but three pairwise comparisons, while head-body length variation was significant in half of all comparisons (Table 3). Significant variation in tail length was found only between Zealandia and Eglinton mice.

Centroid size differed significantly in three pairwise comparisons (Table 3). Zealandia and Eglinton mandibles had significantly larger centroid size than Pureora and Craigieburn mandibles (Table 2; Figure 3). Under regression, centroid size did not vary significantly with weight $\left(\mathrm{R}^{2}=0.026\right.$, tdf $\left.=103, P=0.056\right)$ or head-body length $\left(R^{2}=-0.003, \mathrm{tdf}=104, P=0.399\right)$.

Genetic haplotype was a significant predictor of body weight $\left(R^{2}=0.142\right.$, $\left.\operatorname{tdf}=112, P=<0.0001\right)$ and centroid size $\left(R^{2}=0.163, t d f=104, P=<0.0001\right)$, but not head-body length $\left(R^{2}=0.002, t d f=114, P=0.263\right)$.

Weight, tail length and centroid size data were not normally distributed (Shapiro-Wilks $P<0.001$ ). Head-body length data were normal (Shapiro-Wilks $P>0.05$ ), but displayed unequal group variances with the BrownForsythe test $(P<0.0001)$.

[Here Table 2 and 3] 
[Here Figure 3]

\section{BIOMECHANICAL DIFFERENCES}

Biomechanical advantage is a measure of the efficacy of the mandible to exert bite force and occlude the incisor teeth. The biomechanical advantage ratio data displayed normality $(P>0.05)$ but unequal variance $(P<0.0001)$. Biomechanical advantage varied significantly between all but three populations (Table 4). Overall, Zealandia mice had the highest masseter muscle mechanical advantage, and the lowest temporalis muscle advantage (Figure 4). Eglinton Valley mice had the highest temporalis mechanical advantage, while Craigieburn and Hollyford forest mice had the lowest masseter mechanical advantage (Figure 4). Eglinton, Craigieburn and Hollyford mice did not differ significantly in temporalis mechanical advantage (Table 5). Furthermore, Zealandia and Eglinton mice did not differ significantly in masseter mechanical advantage. The largest variation in biomechanical advantage was found between Zealandia and Craigieburn mice, differing significantly across all mechanical ratios. There was no significant difference found in biomechanical advantage between Craigieburn, Hollyford, and Pureora mice.

[Here Table 4 and Figure 4]

\section{MANDIBLE SHAPE DIFFERENCES}

The centroid size - Procrustes coordinates regression was significant for allometry $(P<0.0001)$, with size accounting for $4.38 \%$ of shape variance. All subsequent analyses were performed using the regression residuals to visualise variation in shape without allometric influence.

The first five principal components each accounted for $>5 \%$ variance, accumulating to $65.5 \%$ of total variance. Mandible shape varied significantly between forest populations $(P<0.0001$ for variation in Procrustes distances). Shape differentiation was visualised using a PCA plot (Figure 5), where PC1 and PC2 accounted for $24.10 \%$ and $16.08 \%$ of total variation respectively. $90 \%$ confidence ellipses of each population mean show a clear separation between Zealandia, Pureora, and the South Island (Craigieburn, Eglinton and Hollyford) samples along the first PC axis. Zealandia mandibles display a broader mandible profile at the positive end of 10 
the axis, with a slimmer, distally shifted coronoid process, smaller condyle process and larger angular process (PC1 pink outline; Figure 5) compared to the South Island mandible shapes. South Island mandibles present a shorter angular process and slightly longer mandible profile (PC1 blue outline; Figure 5) than the North Island mandibles, while Pureora mandible shapes fall between these two shape extremes. The second PC axis differentiates Zealandia mandibles once again, but in opposition to Pureora and Eglinton mandible shapes (Figure 5). Zealandia mandibles display a much broader and shorter mandible shape at the positive end of the second axis (PC2 pink outline; Figure 5), including a longer angular process than Eglinton and Pureora mandible shapes. At the negative end, Pureora and Eglinton mandibles are slim and elongated (PC2 blue outline; Figure 5); Hollyford and Craigieburn mandible shapes fall between these two shape extremes along the second axis.

[Here Figure 5 ]

The Mahalanobis distances were significantly different between all group means, the greatest found between Zealandia and Craigieburn (7.9, $P<0.0001)$. North and South Island groups were effectively separated along the first CV axis, accounting for $47.2 \%$ of variation (Figure 6). North Island mandibles differed from those in the South Island by having a broader overall profile with larger angular processes (CV1 pink outline; Figure 6).

[Here Figure 6]

The overall strength of association, i.e. RV coefficient, between the two PLS blocks (mandible shape and covariates) was 0.153 . The null hypothesis of complete independence between shape and covariate blocks was rejected $(P<0.0001)$. Rainfall was the most significant covariate with mandible shape, accounting for $80.9 \%$ of total covariation $(P<0.0001)$, followed by altitude $(18.8 \%, P<0.0001)$. Along PLS1, lower rainfall coincided with a broader mandible shape (blue outline; Figure 7a). Highest rainfall at Hollyford Valley was associated with a depressed coronoid process and slimmer angular process (pink outine; Figure 7a). Along PLS2, highest altitude coincided with a slimmer angular process and alveolar region (pink outline; Figure 7b) in comparison to lower altitude locations (blue outline; Figure $7 b$ ).

[Here Figure 7] 


\section{DISCUSSION}

This study found significant variation in body size and mandible shape between five samples of wild house mice living in different forest types on the two main islands of New Zealand. Each forest represented unique habitat conditions that may have prompted mandible shape and body size variation.

Previous studies have found significant variation in the body size of small mammals from island versus continental populations, and between islands of varying size and isolation (Millien 2006; Lomolino et al. 2012; Martínková et al. 2013). This change in body mass can be attributed to altered resource abundance, ecological release, and population demographics, all of which are influenced by a number of environmental factors including climate and island size (McNab 2010; Millien 2011; Lomolino et al. 2012). In an Australian study, Tomlinson \& Withers (2008) found $M$. domesticus house mouse body mass to be heaviest at higher latitudes and eastern longitudes, where the cooler habitats confer greater rainfall variability and less arid conditions. The larger bodies of South Island mice compared with North Island mice could be linked to higher food availability during beech seed masts, when most South Island mice were collected. Body size may also vary with local climatic conditions. More extensive sampling from a greater variety of habitats is recommended to extend these preliminary findings, which are limited in sample size and variable collection and so are unsuitable for any more than preliminary statistical analyses. We suggest sampling environmental conditions simultaneously to compare body size variation with hypotheses derived from Bergmann's rule.

House mouse mandibles have repeatedly shown shape variability on islands and continents alike (Mikula et al. 2007; Siahsarvie et al. 2012; Renaud et al. 2015). Mandible shape variation has been previously associated with niche specialisation, colonisation and dietary change (Michaux et al. 2007; Anderson et al. 2014; Renaud et al. 2015). Zealandia sanctuary house mice had the most distinct mandible shape compared with all other forest populations, repeatedly displaying a broad mandible profile and large angular process. The significantly larger mandible centroid size of Zealandia mice suggests they can exert higher mechanical loading on the jaw than can Craigieburn and Pureora mice (Renaud et al. 2015). Coupled with a high masseter mechanical advantage, these traits suggest Zealandia mouse mandibles are efficient at processing tough food items, because these 12 
same traits have been previously associated with a diet dominated by resistant plant foods (Satoh 1997; Michaux et al. 2007; Renaud et al 2010; Baverstock et al. 2013). On the other hand, Zealandia was the only location in this study where mice did not coexist with rats, or any other introduced mammals. Previous studies have found invertebrate prey to dominate the diet of insular house mice (Copson 1986; Le Roux et al. 2002; Angel et al. 2009; Renaud et al. 2015) and to display increased body size (Goldwater et al. 2012) in the absence of rats and other mammals.

Pureora forest mice showed mandible shapes intermediate between Zealandia and South Island mice on the first axes of both PCA and CVA plots. However, along PC2 and CV2 axes, Pureora mandible shapes clustered closely with South Island samples, highlighting the distinctiveness of mandible shapes in Zealandia mice. With a significantly greater masseter/molar advantage than Craigieburn and Hollyford samples and significantly lower advantage than Karori and Eglinton, Pureora mouse mandibles appear to represent an intermediate phenotype in the context of this study. King et al. $(1996 a, b)$ collected most mice from an area in Pureora Forest with dense ground cover, least frequented by rats. Competition and predation from rats (Bridgman et al. 2013) could be confining Pureora mice to a smaller realised niche, constricting body size. Smaller body size may enable mice to better hide and escape from rats in the dense ground cover, where edible vegetation and invertebrates are abundant (King et al. 1996a, b; Goldwater et al. 2012).

South Island house mice inhabiting beech spp. forest presented overall mandible shapes most consistent with soft food consumption (Michaux et al. 2007; Anderson et al. 2014; Renaud et al. 2015). The longer condyle process extended the distance to the coronoid process, increasing the length of the temporalis inlever which acts to move the incisors into occlusion (Satoh 1997; Baverstock et al. 2013; Anderson et al. 2014). The higher mechanical advantage of the temporalis muscle enables more efficient occlusion compared with Zealandia mandibles, and has been linked to prey-catching activity in Guillou Island house mice (Renaud et al. 2015). Softer foods require less mechanical force to process, resulting in slimmer mandible profiles as observed in this study (Renaud et al. 2010; Anderson et al. 2014; Renaud et al. 2015). Eglinton mandibles also held the second highest masseter advantage score, suggesting these mice possess a mandible adept for processing both soft 
and hard food types. Previous studies by Fitzgerald et al (1996) and Wilson and Lee (2010) concur that house mice feed on both caterpillars and seeds during seed mast events.

Genetic background can also influence mandible shape and body size of mice. Scriven \& Bauchau (1992) found hybrid mice on the Isle of May had significantly larger body size than their two genetically and morphologically distinct parental populations, and displayed a mandible shape phenotype that was intermediate between the two parental populations. Renaud et al. (2012) also observed laboratory-bred hybrid mouse mandibles to differ in both shape and size from parental groups, suggesting genetic background can have a significant influence on mandible shape in the absence of environmental stimuli. The discrimination of individuals across the PCA and CVA plots in this study does not appear have any genetic influence. However, genetic haplotype was a significant predictor of mandible centroid size and body weight in regression analyses. Pureora and Craigieburn are both likely to be pure-bred domesticus mice, while Hollyford, Eglinton and Karori are all assumed to be domesticus - castaneusNZ.1 hybrids. These previous studies indicate there may be haplotype-related variation in New Zealand mice that could not be identified in this study.

PLS analysis revealed a significantly greater correlation between mandible shape and rainfall than with any other covariate, including haplotype and presence of rats. Higher rainfall locations were associated with 'soft food' mandible shapes (e.g., South Island samples). By contrast, lower rainfall areas coincided with mandible shapes more adept at processing resistant food (e.g., Zealandia). The covariation of mandible shape and rainfall is consistent with patterns observed in the biomechanical analysis. Hypothetically, foods in higher rainfall areas may be softer simply because they contain more moisture, such as in litter invertebrates; of course, such speculations would require extensive further research. The observed trend between shape and rainfall could also be tied to net primary productivity (McNab 2010; Huston \& Wolverton 2011; Alhajeri \& Steppan 2016). Higher annual rainfall may result in elevated plant productivity that supports increased food availability, but must be considered with temperature and other influencing factors simultaneously. The extensive collection of South Island mice during seed mast years was a likely influence on mandible shape and body size in this current study. Hence, the observed variation in mandible shape between separate forest populations could arise from 
differences in the quantities of hard versus soft food materials included in the diet, suggesting some possible interpretations that could be tested from future dietary data. Sample collection over four decades may have also influenced the results reported in this study. Zealandia samples were the most distinct, but are thirty years younger than the other samples. The effect of long-term processes, such as climate change, on food and habitat resources could contribute to the differences observed in modern mice compared with those collected in the 70 s and 80 s.

\section{CONCLUSIONS}

The present study has provided observations of significant patterns of variation within New Zealand house mice from the North and South Islands that suggests hypotheses for future investigations. North Island mice differed significantly from South Island mice in mandible shape and biomechanical advantage, for reasons not identified here but potentially consistent with the mechanical requirements of harder versus softer food diets respectively. The body size of North Island mice was also significantly smaller than South Island mice. We recommend that further environmental, dietary, and genetic data be collected during a purpose-designed sampling programme, specifically to clarify the origins of shape variation found between mouse mandibles that could not be identified by this exploratory study.

\section{ACKNOWLEDGEMENTS}

We are grateful to the staff of Zealandia Wildlife Sanctuary and to the curators of Te Papa and Auckland Institute Museums for providing ample material for this study. We also thank Lyn Hunt for her discussions on the statistical analysis of morphometric data and Barry O'Brien for his technical help with the photography equipment. We are very grateful to Bruce Patty for his general assistance with purchases and sample storage. Annie West acknowledges the University of Waikato for providing the facilities, equipment and funding for the practical work, and the Freemasons Society for a scholarship, supporting attendance at the 7th European Congress of Mammalogy in Sweden to present preliminary findings. We are especially grateful to two very thorough referees, whose perceptive comments substantially improved the MS. 


\section{REFERENCES}

Adler GH, Levins R 1994. The island syndrome in rodent populations. The Quarterly Review of Biology 69(4): 473-90.

Alhajeri BH, Steppan SJ 2016. Association between climate and body size in rodents: A phylogenetic test of Bergmann's rule. Mammalian Biology - Zeitschrift für Säugetierkunde 81(2): 219-225.

Anderson P, Renaud S, Rayfield E 2014. Adaptive plasticity in the mouse mandible. BioMed Central Evolutionary Biology 14(85).

Angel A, Wanless R, Cooper J 2009. Review of impacts of the introduced house mouse on islands in the Southern Ocean: are mice equivalent to rats? Biological Invasions 11(7): 1743-1754.

Baverstock H, Jeffery NS, Cobb SN 2013. The morphology of the mouse masticatory musculature. Journal of Anatomy 223(1): 46-60.

Berry RJ 1964. The evolution of an island population of the house mouse. Evolution 18(3): 468-483.

Blick R, Bartholomew R, Burrell T, Burns KC 2008. Successional dynamics after pest eradication in the Karori Wildlife Sanctuary. New Zealand Natural Sciences 33: 3-14.

Bookstein FL 1986. Size and shape spaces for landmark data in two dimensions. Statistical Science 1(2): 181222.

Bookstein FL 1991. Morphometric tools for landmark data: Geometry and Biology. Cambridge, UK, Cambridge University Press.

Bridgman LJ, Innes J, Gillies C, Fitzgerald NB, Miller S, King CM 2013. Do ship rats display predatory behaviour towards house mice? Animal Behaviour 86(2): 257-268.

Choquenot D, Ruscoe WA 2000. Mouse population eruptions in New Zealand forests: the role of population density and seedfall. Journal of Animal Ecology 69(6): 1058-1070.

Cooke SB, Terhune CE 2015. Form, function, and geometric morphometrics. The Anatomical Record 298(1): 528. 
Copson GR 1986. The diet of the introduced rodents Mus musculus and Rattus rattus on sub-Antarctic Macquarie Island. Wildlife Research 13(3): 441-445.

Crompton A, Parker P 1978. Evolution of the mammalian masticatory apparatus: the fossil record shows how mammals evolved both complex chewing mechanisms and an effective middle ear, two structures that distinguish them from reptiles. American Scientist 66(2): 192-201.

Doudna JW, Danielson BJ 2015. Rapid morphological change in the masticatory structures of an important ecosystem service provider. Public Library of Science (PLoS) ONE 10(6): e0127218.

Dryden IL, Mardia KV 1998. Statistical shape analysis. Chichester; New York, John Wiley \& Sons.

Fitzgerald BM, Daniel MJ, Fitzgerald AE, Karl BJ, Meads MJ, Notman PR 1996. Factors affecting the numbers of house mice (Mus musculus) in hard beech (Nothofagus truncata) forest. Journal of the Royal Society of New Zealand 26(2): 237-249.

Goldwater N, Perry GLW, Clout MN 2012. Responses of house mice to the removal of mammalian predators and competitors. Austral Ecology 37(8): 971-979.

Hiiemae K 1971a. The structure and function of the jaw muscles in the rat (Rattus norvegicus L.) I. Their anatomy and internal architecture. Zoological Journal of the Linnean Society 50: 75-99.

Hiiemae K 1971b. The structure and function of the jaw muscles in the rat (Rattus norvegicus L.): III. The mechanics of the muscles. Zoological Journal of the Linnean Society 50(1): 111-132.

Innes J, Warburton B, Williams D, Speed H, Bradfield P 1995. Large-scale poisoning of ship rats (Rattus-rattus) in indigenous forests of the North-Island, New-Zealand. New Zealand Journal of Ecology 19(1): 5-17. Kendall DG 1984. Shape Manifolds, Procrustean Metrics, and Complex Projective Spaces. Bulletin of the London Mathematical Society 16(2): 81-121.

Kendall DG 1989. A Survey of the Statistical Theory of Shape. 87-99.

King CM 1983. The relationships between beech (Nothofagus sp.) seedfall and populations of mice (Mus musculus), and the demographic and dietary responses of stoats (Mustela erminea), in three New Zealand forests. Journal of Animal Ecology 52(1): 141-166. 
King CM, Gaukrodger DJ, Ritchie NA 2015. The drama of conservation : the history of Pureora Forest, New Zealand, Wellington : Department of Conservaton : Springer.

King CM, Innes JG, Flux M, Kimberley MO 1996a. Population biology of small mammals in Pureora Forest park:

2. The feral house mouse (Mus musculus). New Zealand Journal of Ecology 20(2): 256-269.

King CM, Innes JG, Flux M, Kimberley MO, Leathwick JR, Williams DS 1996b. Distribution and abundance of small mammals in relation to habitat in Pureora Forest park. New Zealand Journal of Ecology 20(2): 214-240.

King CM, Alexander A, Chubb T, Cursons R, MacKay J, McCormick H, Murphy E, Veale A, Zhang H 2016. What can the geographic distribution of mtDNA haplotypes tell us about the invasion of New Zealand by house mice Mus musculus? Biological Invasions 18(6): 1551-1565.

Klingenberg CP 2011. MorphoJ: an integrated software package for geometric morphometrics. Molecular Ecology Resources 11: 353-357.

Klingenberg CP 2016. Size, shape, and form: concepts of allometry in geometric morphometrics. Development Genes and Evolution 226(3): 113-137.

Klingenberg CP, Navarro N 2012. Development of the mouse mandible: a model system for complex morphological structures. In: Macholan M, Baird SJE, Munclinger P, Pialek J ed. Evolution of the House Mouse. Cambridge, England, Cambridge University Press.

Le Roux V, Chapuis JL, Frenot Y, Vernon P 2002. Diet of the house mouse (Mus musculus) on Gillou Island, Kerguelen archipelago, Subantarctic. Polar Biology 25: 49-57.

Ledevin R, Chevret P, Ganem G, Britton-Davidian J, Hardouin EA, Chapuis J-L, Pisanu B, da Luz Mathias M, Schlager S, Auffray J-C and others 2016. Phylogeny and adaptation shape the teeth of insular mice. Proceedings of the Royal Society B: Biological Sciences 283(1824).

Lomolino MV 2005. Body size evolution in insular vertebrates: generality of the island rule. Journal of Biogeography 32: 1683-1699.

Lomolino MV, Sax DF, Palombo MR, van der Geer AA 2012. Of mice and mammoths: evaluations of causal explanations for body size evolution in insular mammals. Journal of Biogeography 39(5): 842-854. 
Martínková N, Barnett R, Cucchi T, Struchen R, Pascal M, Pascal M, Fischer MC, Higham T, Brace S, Ho SY 2013. Divergent evolutionary processes associated with colonization of offshore islands. Molecular ecology 22(20): 5205-5220.

McDonald RA, Vaughan N 1999. An efficient way to prepare mammalian skulls and bones. Mammalian Review 29: $265-266$.

McNab BK 2010. Geographic and temporal correlations of mammalian size reconsidered: a resource rule. Oecologia 164: 13-23.

Medina Al, Martı DA, Bidau CJ 2007. Subterranean rodents of the genus Ctenomys (Caviomorpha, Ctenomyidae) follow the converse to Bergmann's rule Journal of Biogeography 34: 1439-1454.

Michaux J, Chevret P, Renaud S 2007. Morphological diversity of Old World rats and mice (Rodentia, Muridae) mandible in relation with phylogeny and adaptation. Journal of Zoological Systematics and Evolutionary Research 45(3): 263-279.

Mikula O, Auffray JC, Macholan M 2010. Asymmetric size and shape variation in the Central European transect across the house mouse hybrid zone. Journal of the Linnean Society 101(1): 13-27.

Miller AP, Webb PI 2001. Diet of house mice (Mus musculus L.) on coastal sand dunes, Otago, New Zealand. New Zealand Journal of Zoology 28(1): 49-55.

Millien V 2006. Morphological evolution is accelerated among island mammals Public Library of Science (PLOS) Biology 4(11): 2165-2165.

Millien V 2011. Mammals evolve faster on smaller islands. Evolution 65(7): 1935-1944.

Mitteroecker P, Gunz P 2009. Advances in Geometric Morphometrics. Evolutionary Biology 36(2): 235-247. Monteiro LR 1999. Multivariate regression models and geometric morphometrics: The search for causal factors in the analysis of shape. Systematic Biology 48(1): 192-199.

Murphy EC 1992. The effects of a natural increase in food-supply on a wild population of house mice. New Zealand Journal of Ecology 16(1): 33-40.

Norton D, Kelly D 1988. Mast seeding over 33 years by Dacrydium cupressinum Lamb.(rimu)(Podocarpaceae) in New Zealand: the importance of economies of scale. Functional ecology: 399-408. 
O’Donnell CF, Weston KA, Monks JM 2017. Impacts of introduced mammalian predators on New Zealand's alpine fauna. New Zealand Journal of Ecology 41(1): 01-22.

Renaud S 2005. First upper molar and mandible shape of wood mice (Apodemus sylvaticus) from northern Germany: ageing, habitat and insularity. Mammalian Biology - Zeitschrift für Säugetierkunde 70(3): 157-170.

Renaud S, Auffray JC 2010. Adaptation and plasticity in insular evolution of the house mouse mandible. Journal of Zoological Systematics and Evolutionary Research 48(2): 138-150.

Renaud S, Alibert P, Auffray JC 2012. Modularity as a source of new morphological variation in the mandible of hybrid mice. BioMed Central Evolutionary Biology 12: 16.

Renaud S, Gomes Rodrigues H, Ledevin R, Pisanu B, Chapuis J-L, Hardouin EA 2015. Fast evolutionary response of house mice to anthropogenic disturbance on a Sub-Antarctic island. Biological Journal of the Linnean Society 114(3): 513-526.

Rohlf FJ 1990. Morphometrics. Annual Review of Ecology and Systematics 21: 299-316.

Rohlf FJ 2005. Geometric morphometrics simplified. Trends in Ecology \& Evolution 20(1): 13-14.

Rohlf FJ 2015. TPSDig Version 2.19. SUNY Stony Brook Morphometrics.

Rohlf JF 1999. Shape Statistics: Procrustes Superimpositions and Tangent Spaces. Journal of Classification 16(2): 197-223.

Ruscoe WA, Murphy EC 2005. House Mouse. In: King CM ed. The Handbook of New Zealand Mammals. 2nd ed. Melbourne, AUS, Oxford University Press.

Ruscoe WA, Wilson D, McElrea L, McElrea G, Richardson SJ 2004. A house mouse (Mus musculus) population eruption in response to rimu (Dacrydium cupressinum) seedfall in southern New Zealand. New Zealand Journal of Ecology 28(2): 259-265.

Russell JC 2012. Spatio-temporal patterns of introduced mice and invertebrates on Antipodes Island. Polar Biology 35(8): 1187-1195. 
Satoh K 1997. Comparative functional morphology of mandibular forward movement during mastication of two murid rodents, Apodemus speciosus (Murinae) and Clethrionomys rufocanus (Arvicolinae). Journal of Morphology 231: 131-142.

Scriven PN, Bauchau V 1992. The effect of hybridization on mandible morphology in an island population of the house mouse. Journal of Zoology 226: 573-583.

Searle JB, Jamieson PM, Gündüz I, Stevens MI, Jones EP, Gemmill CEC, King CM 2009. The diverse origins of New Zealand house mice. Proceedings of the Royal Society B: Biological Sciences 276(1655): 209-217. Siahsarvie R, Auffray JC, Darvish J, Rajabi-Maham H, Yu HT, Agret S, Bonhomme F, Claude J 2012. Patterns of morphological evolution in the mandible of the house mouse Mus musculus (Rodentia: Muridae). Biological Journal of the Linnean Society 105(3): 635-647.

Slice DE 2007. Geometric morphometrics. Annual Review of Anthropology 36: 261-268.

Tomlinson S, Withers PC 2009. Biogeographical effects on body mass of native Australian and introduced mice, Pseudomys hermannsburgensis and Mus domesticus: an inquiry into Bergmann's Rule. Australian Journal of Zoology 56: 423-430.

Wilson DJ, Lee WG 2010. Primary and secondary resource pulses in an alpine ecosystem: snow tussock grass (Chionochloa spp.) flowering and house mouse (Mus musculus) populations in New Zealand. Wildlife Research 37(2): 89-103.

Zelditch M, Swiderski DL, Sheets HD 2012. Geometric morphometrics for biologists: a primer. Amsterdam, Elsevier/Academic Press.

\section{TABLE CAPTIONS}

Table 1 Environmental variables associated with each forest habitat included in this study.

Table 2 Body measurements of adult mice in New Zealand forests (mean \pm SD).

Table 3 P-values from pairwise comparison, with Bonferroni and Dunnett T3 (HBL) correction, of mouse body measurements between forest populations (HBL: Head-body length; CS: Centroid size). Bold, red text indicates significant P-values $\leq 0.05$.

21 
Table 4 P-values from pairwise comparison, with Dunnett's T3 correction, of the biomechanical advantage ratios between forest populations. Bold, red text indicates significant P-values $\leq 0.05$.

\section{FIGURE CAPTIONS}

Figure 1 Distinct components of the house mouse mandible in Michaux et al. (2007). "Mandible of a murine rodent (Apodemus) in lateral view. (a) Main anatomical parts. (b) Attachment area and approximate line of action of the main masticatory muscles (after Satoh 1997)". Permissions obtained from John Wiley and Sons.

Figure 2 House mouse mandible in lateral view. (a) Placement of 16 landmarks to sample mandible shape. (b) Biomechanical inlever length (dotted lines) based on muscle attachment zones and outlever length (solid lines) based on bite zones.

Figure 3 Variation in body and centroid size between each forest population. (a) Body weight; (b) Head-body length; (c) Tail length; (d) Centroid size. Each icon corresponds to an individual specimen.

Figure 4 Biomechanical indices between forest populations. (a) Ratio of the temporalis muscle (inlever) and incisor (outlever); (b) Ratio of the masseter muscle (inlever) and molar (outlever).

Figure 5 PCA plot of mandible shape differences between forest populations with PC1 and PC2. Each dot represents a specimen, with $90 \%$ confidence ellipses around the mean of each population. Procrustes deformation warped outlines represent the change in mandible shape along each axis; blue represents mandible shape at far left of the axis, pink represents mandible shape at far right of the axis.

Figure 6 CVA plot displaying maximum differentiation of pre-defined forest groups with CV1 and CV2. Procrustes deformation warped outlines represent the change in mandible shape along each axis; blue represents mandible shape at far left of the axis, pink represents mandible shape at far right of the axis.

Figure 7 Mandible shape change with significant PLS covariates. (a) Mandible shape change with rainfall from low (blue shape) to high (pink shape) rainfall. (b) Mandible shape change with altitude from low (blue shape) to high (pink shape) altitudes. 
Table 1 Environmental variables associated with each forest habitat included in this study.

\begin{tabular}{|c|c|c|c|c|c|c|c|}
\hline & $\begin{array}{l}\text { Altitude } \\
\text { (m) }\end{array}$ & $\begin{array}{c}\text { Annual } \\
\text { rainfall } \\
(\mathrm{mm})\end{array}$ & $\begin{array}{c}\text { Temperature } \\
\left({ }^{\circ} \mathrm{C}\right)\end{array}$ & $\begin{array}{l}\text { Latitude - } \\
\text { Longitude }\end{array}$ & Habitat & Rats & Reference \\
\hline Pureora & $550-700$ & 1759 & $6-15.3$ & $\begin{array}{l}38.6947^{\circ} \mathrm{S} \\
175.5612^{\circ} \mathrm{E}\end{array}$ & $\begin{array}{c}\text { Pine }(P \text {. radiata }) \text { and } \\
\text { podocarp forest }\end{array}$ & Yes & $\begin{array}{l}\text { King et al. } \\
(1996 a, b)\end{array}$ \\
\hline Craigieburn & $790-1340$ & 1450 & $1-13$ & $\begin{array}{l}43.1509^{\circ} \mathrm{S} \\
171.7119^{\circ} \mathrm{E}\end{array}$ & $\begin{array}{l}\text { Mountain } \\
\text { beech forest ( } F \text {. } \\
\text { cliffortioides) }\end{array}$ & Yes & King (1983) \\
\hline Hollyford & $90-370$ & 4250 & $1-10$ & $\begin{array}{c}44.45^{\circ} \mathrm{S} \\
168.10^{\circ} \mathrm{E}\end{array}$ & $\begin{array}{l}\text { Mixed, including } \\
\text { silver beech ( } L \text {. } \\
\text { menziesii) } \\
\text { forest }\end{array}$ & Yes & King (1983) \\
\hline Eglinton & $270-550$ & 2300 & $0-8$ & $\begin{array}{l}44.50^{\circ} \mathrm{S} \\
168.05^{\circ} \mathrm{E}\end{array}$ & $\begin{array}{l}\text { Mostly red beech } \\
\text { forest ( } F . \text { fusca) }\end{array}$ & Yes & $\begin{array}{l}\text { King (1983), } \\
\text { Murphy } \\
\text { (unpub.) }\end{array}$ \\
\hline Zealandia & $160-380$ & 1265 & $0.5-28.6$ & $\begin{array}{l}41.2838^{\circ} \mathrm{S} \\
174.7409^{\circ} \mathrm{E}\end{array}$ & $\begin{array}{l}\text { Young podocarp } \\
\text { and Pinus radiata }\end{array}$ & No & $\begin{array}{l}\text { Blick et al. } \\
\text { (2007) }\end{array}$ \\
\hline
\end{tabular}


Table 2 Body measurements of adult mice in New Zealand forests (mean \pm SD).

\begin{tabular}{l|cccccccc}
\multicolumn{1}{c}{} & Weight $(\mathbf{g})$ & $\mathbf{n}$ & Tail length $(\mathbf{m m})$ & $\mathbf{n}$ & Head-body length $(\mathbf{m m})$ & $\mathbf{n}$ & Centroid Size & $\mathbf{n}$ \\
\hline Pureora & $16.1 \pm 2.8$ & 38 & $82.2 \pm 4.5$ & 36 & $81.0 \pm 5.0$ & 39 & $16.4 \pm 0.76$ & 32 \\
Craigieburn & $19.4 \pm 2.8$ & 27 & $81.3 \pm 4.7$ & 27 & $92.5 \pm 5.4$ & 27 & $16.3 \pm 0.41$ & 27 \\
Hollyford & $18.2 \pm 1.8$ & 15 & $81.9 \pm 7.2$ & 15 & $86.8 \pm 4.9$ & 15 & $16.8 \pm 0.54$ & 14 \\
Eglinton & $23.5 \pm 2.8$ & 17 & $83.4 \pm 5.8$ & 17 & $88.7 \pm 5.7$ & 18 & $16.9 \pm 0.54$ & 18 \\
Zealandia & $18.7 \pm 3.6$ & 16 & $78.7 \pm 4.2$ & 16 & $76.4 \pm 5.6$ & 16 & $17.0 \pm 0.51$ & 14
\end{tabular}


Table 3 P-values from pairwise comparison, with Bonferroni and Dunnett T3 (HBL) correction, of mouse body measurements between forest populations (HBL: Head-body length; CS: Centroid size). Bold, red text indicates significant P-values $\leq 0.05$.

\begin{tabular}{|c|c|c|c|c|c|c|c|c|c|c|}
\hline & $\begin{array}{l}\text { PUR } \\
\text { ZEAL }\end{array}$ & $\begin{array}{c}\text { PUR } \\
\text { CRAG }\end{array}$ & $\begin{array}{l}\text { PUR } \\
\text { EGL }\end{array}$ & $\begin{array}{c}\text { PUR } \\
\text { HOLL }\end{array}$ & $\begin{array}{l}\text { ZEAL } \\
\text { CRAG }\end{array}$ & $\begin{array}{c}\text { ZEAL } \\
\text { EGL }\end{array}$ & $\begin{array}{l}\text { ZEAL } \\
\text { HOLL }\end{array}$ & $\begin{array}{c}\text { EGL } \\
\text { CRAG }\end{array}$ & $\begin{array}{c}\text { EGL } \\
\text { HOLL }\end{array}$ & $\begin{array}{l}\text { CRAG } \\
\text { HOLL }\end{array}$ \\
\hline Weight & 0.126 & 0.001 & $\leq 0.0001$ & 0.228 & 1.0 & 0.006 & 1.0 & 0.026 & 0.005 & 1.0 \\
\hline Tail & 0.109 & 1.0 & 1.0 & 1.0 & 0.696 & 0.036 & 0.101 & 1.0 & 1.0 & 1.0 \\
\hline HBL & 0.073 & $\leq 0.0001$ & $\leq 0.0001$ & 0.007 & $\leq 0.0001$ & $\leq 0.0001$ & $\leq 0.0001$ & 0.262 & 0.964 & 0.014 \\
\hline CS & 0.093 & 1.0 & 0.030 & 0.532 & 0.006 & 1 & 1.0 & 0.001 & 1.0 & 0.055 \\
\hline
\end{tabular}


Table 4 P-values from pairwise comparison, with Dunnett T3 correction, of the biomechanical advantage ratios between forest populations. Bold, red text indicates significant $P$-values $\leq 0.05$.

\begin{tabular}{l|cccccccccc} 
& PUR & PUR & PUR & PUR & ZEAL & ZEAL & ZEAL & EGL & EGL & CRAG \\
& ZEAL & CRAG & EGL & HOLL & CRAG & EGL & HOLL & CRAG & HOLL & HOLL \\
\hline Mass/Inc & $\leq \mathbf{0 . 0 0 0 1}$ & 0.999 & $\mathbf{0 . 0 3 3}$ & 1.0 & $\leq \mathbf{0 . 0 0 0 1}$ & 0.453 & $\mathbf{0 . 0 0 1}$ & $\mathbf{0 . 0 1}$ & 0.072 & 0.985 \\
Mass/Mol & $\mathbf{0 . 0 1 2}$ & 0.444 & 0.526 & 0.059 & $\leq \mathbf{0 . 0 0 0 1}$ & 0.852 & $\leq \mathbf{0 . 0 0 0 1}$ & $\mathbf{0 . 0 1 8}$ & $\mathbf{0 . 0 0 3}$ & 0.927 \\
Temp/Inc & 0.749 & 0.134 & $\mathbf{0 . 0 0 9}$ & 0.174 & $\mathbf{0 . 0 2 9}$ & $\mathbf{0 . 0 0 4}$ & $\mathbf{0 . 0 2 9}$ & 0.912 & 0.999 & 1.0 \\
Temp/Mol & 0.439 & 0.271 & $\mathbf{0 . 0 1 9}$ & 0.630 & $\mathbf{0 . 0 2 0}$ & $\mathbf{0 . 0 0 3}$ & 0.055 & 0.931 & 0.922 & 1.0
\end{tabular}


(a)

Coronoid process

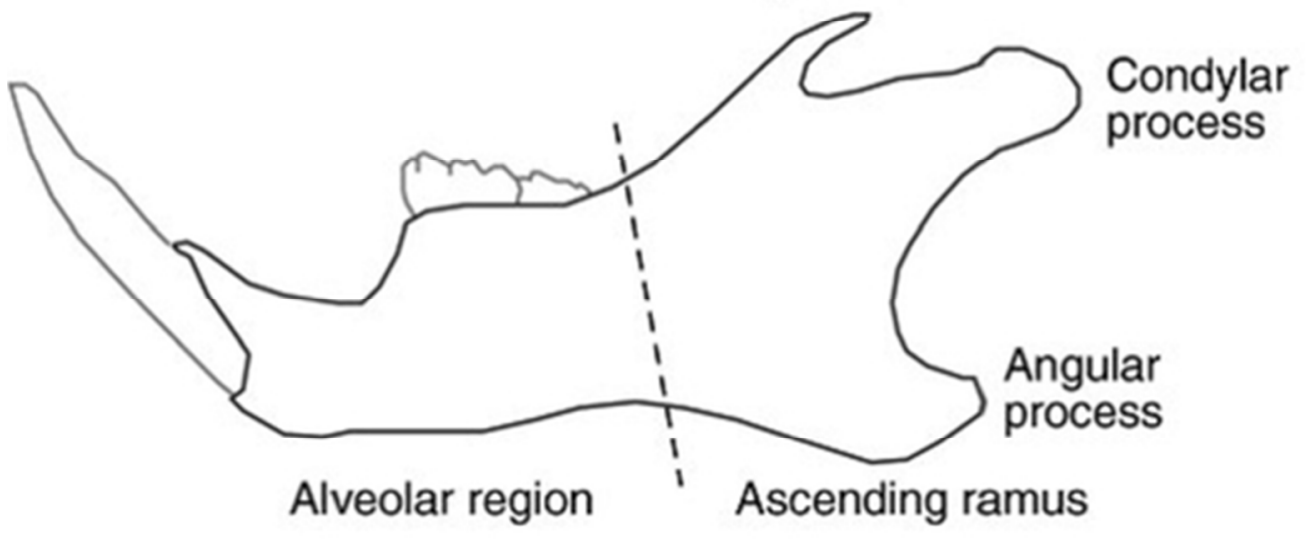

(b)

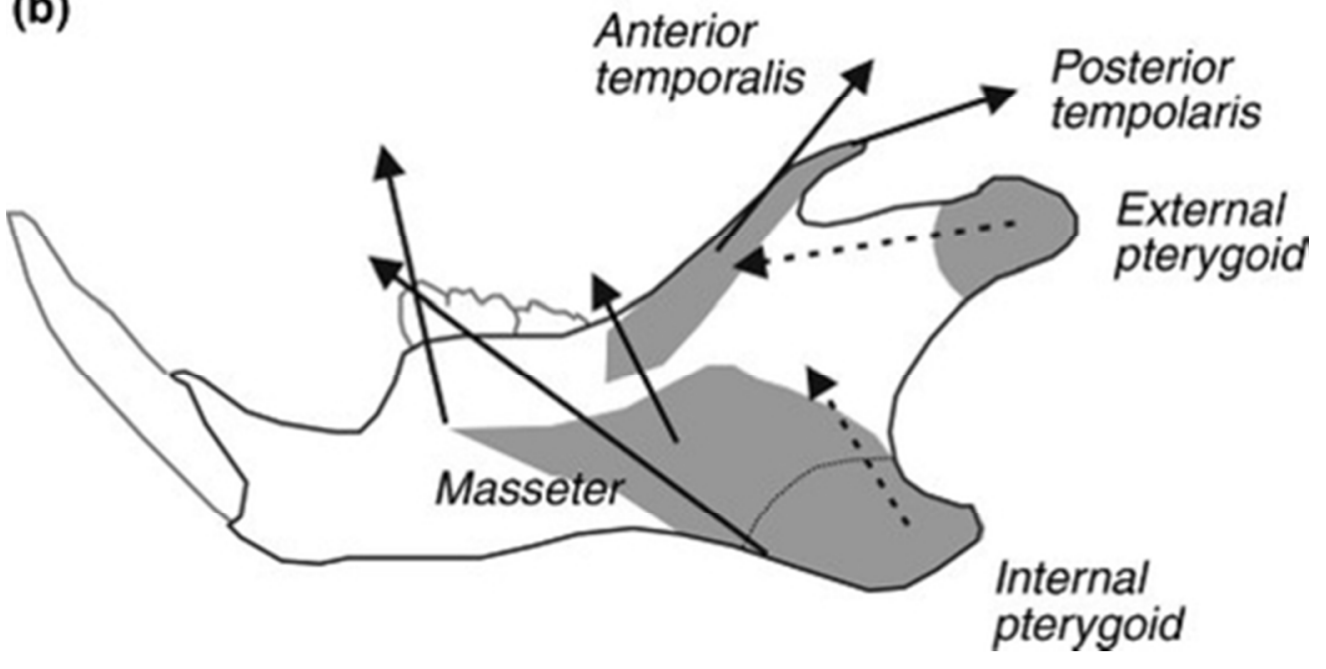

$45 \times 48 \mathrm{~mm}(300 \times 300 \mathrm{DPI})$ 


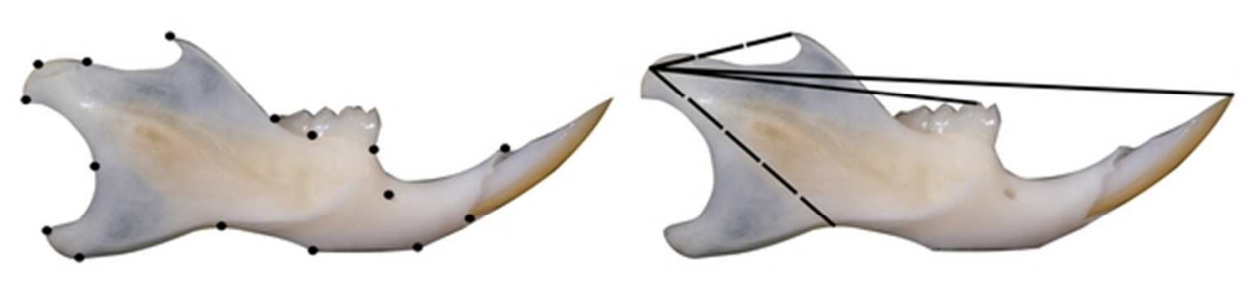

$53 \times 14 \mathrm{~mm}(300 \times 300 \mathrm{DPI})$ 
(a)
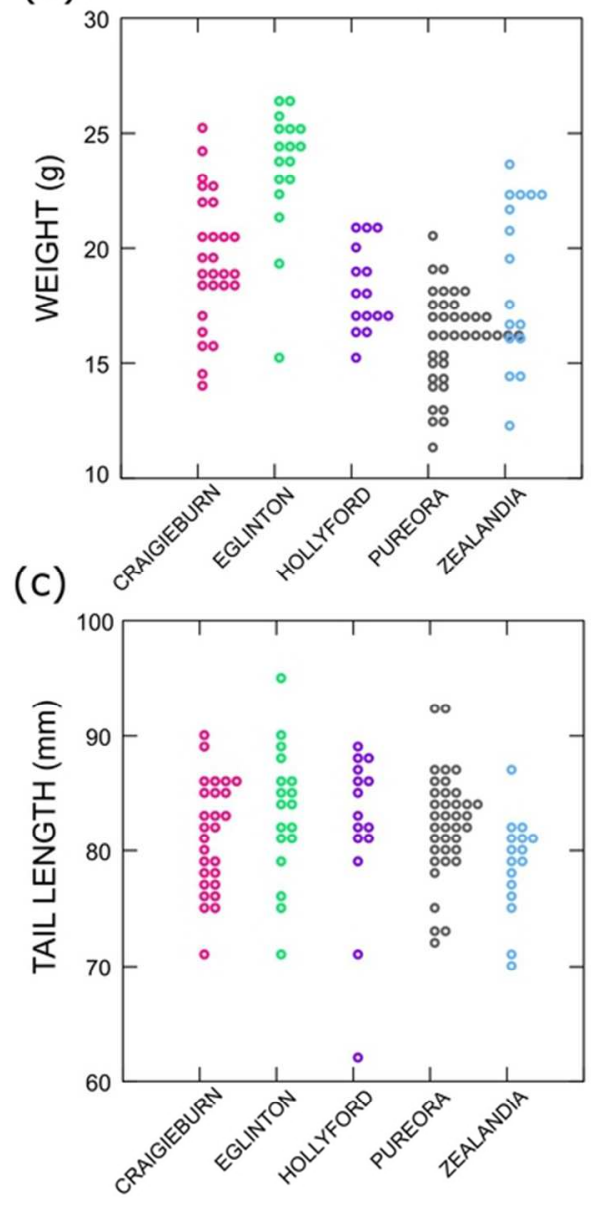

(b)

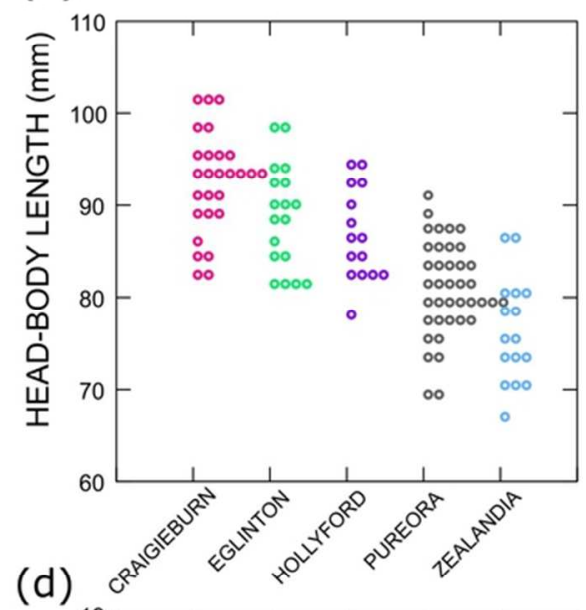

(d) 1

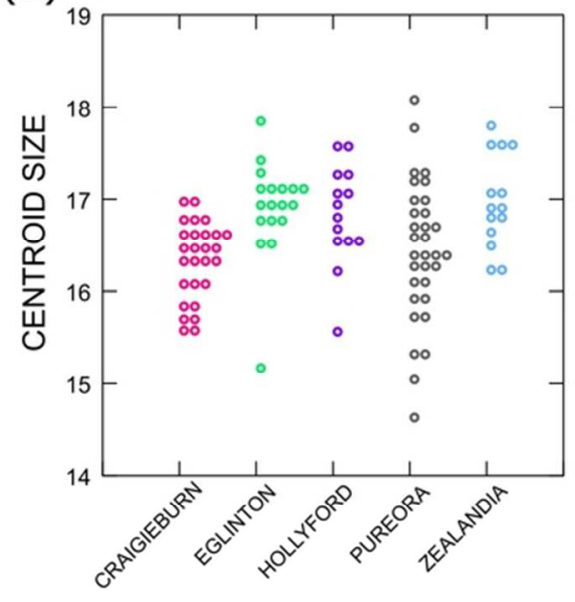

$71 \times 72 \mathrm{~mm}(300 \times 300$ DPI $)$ 

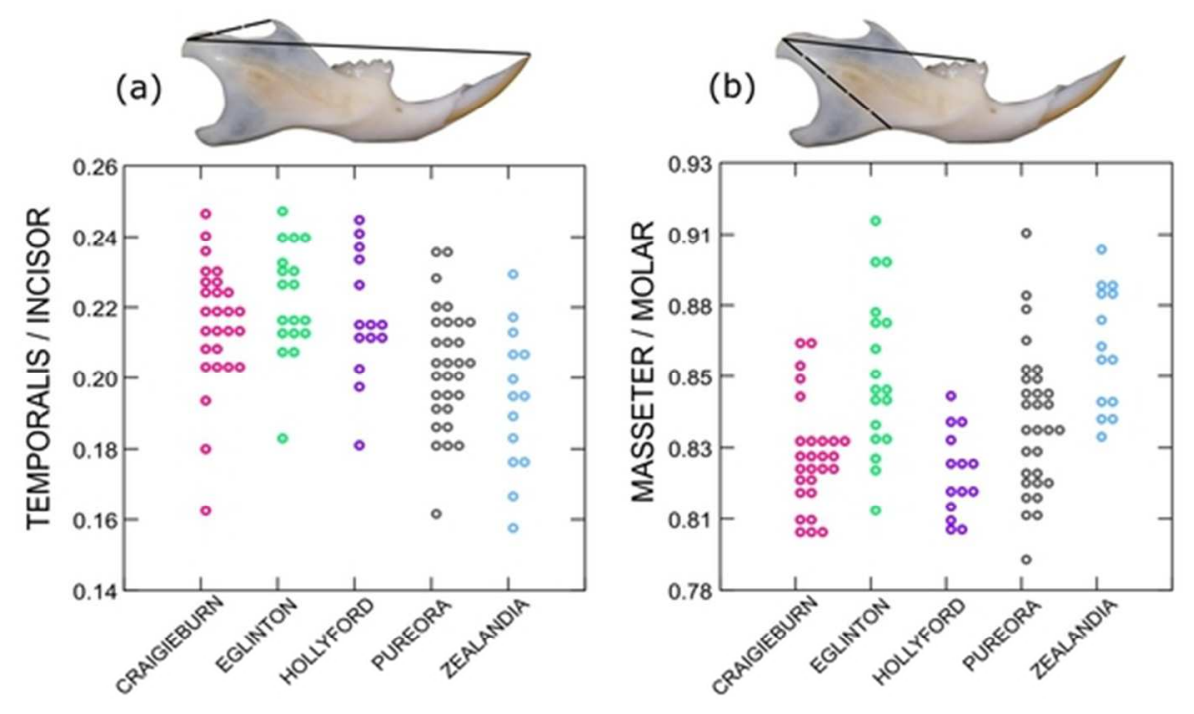

$52 \times 32 \mathrm{~mm}(300 \times 300$ DPI $)$ 


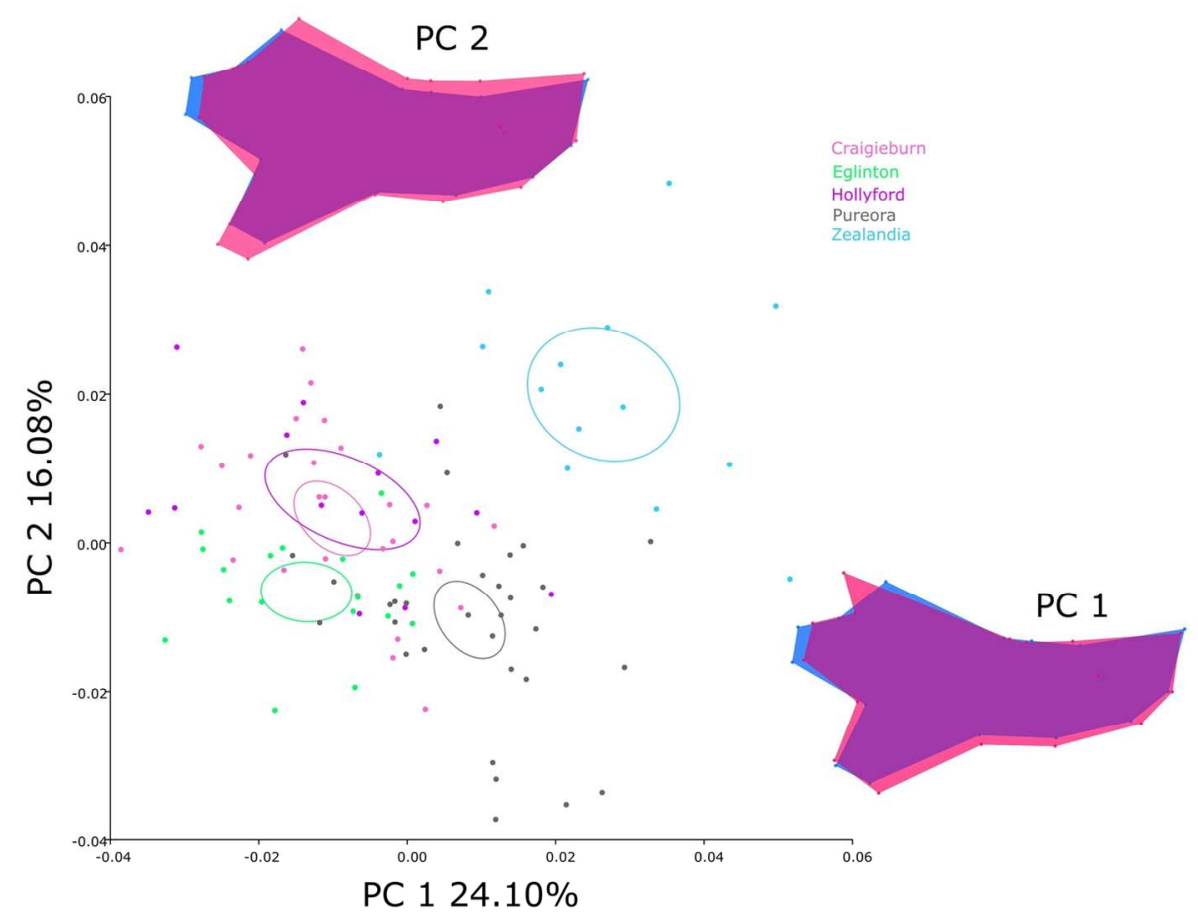

$134 \times 107 \mathrm{~mm}(300 \times 300 \mathrm{DPI})$ 


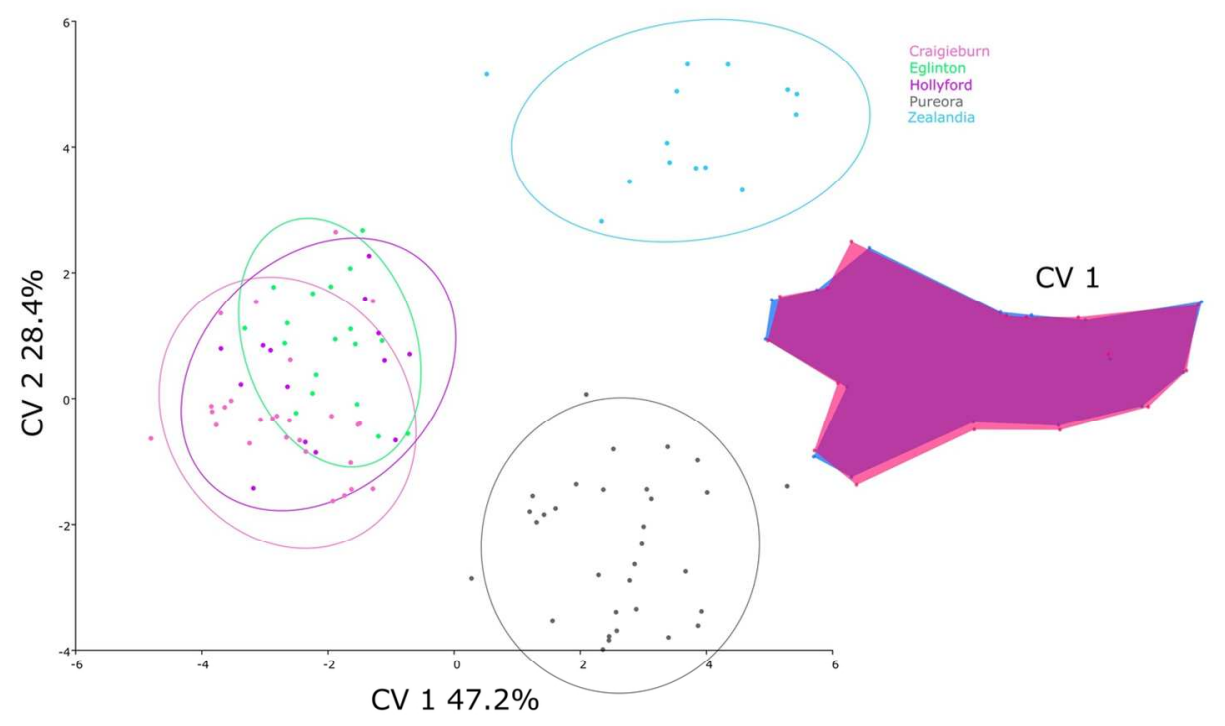

$127 \times 82 \mathrm{~mm}(300 \times 300$ DPI $)$ 

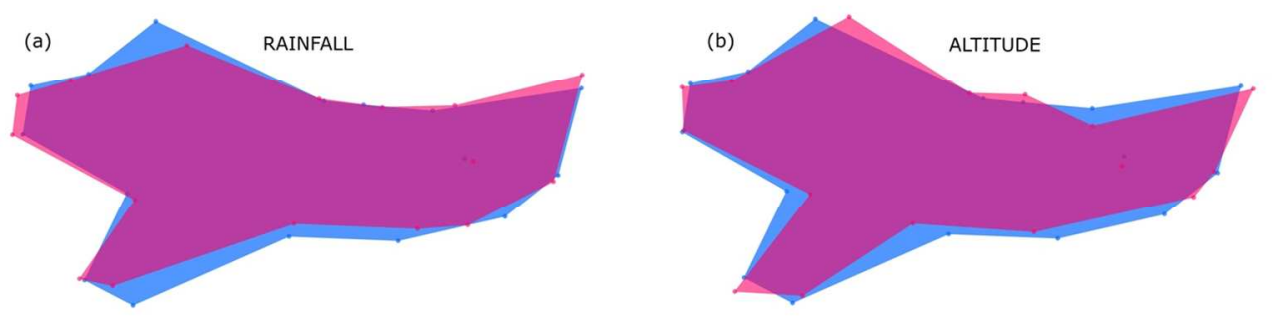

$116 \times 34 \mathrm{~mm}(300 \times 300$ DPI $)$ 